\title{
Protective Effect of Momordica cochinchinensis (L.) Spreng Aril Extract on Essential Testicular Markers in Rats Induced with Valproic Acid
}

\author{
Efecto Protector de Momordica cochinchinensis (L.) Extracto de Aril en \\ Marcadores Testiculares Esenciales en Ratas Inducidas con Ácido Valproico
}

Sitthichai Iamsaard ${ }^{1,2,}$; Wannisa Sukhorum ${ }^{1,2}$; Apichakarn Sampannang1,2 \& Bungorn Sripanidkulchai ${ }^{2}$

SITTHICHAI, I.; WANNISA, S.; APICHAKARN, S. \& BUNGORN, S. Protective effect of Momordica cochinchinensis (L.) spreng aril extract on essential testicular markers in rats induced with valproic acid. Int. J. Morphol., 35(3):992-999, 2017.

SUMMARY: Valproic acid (VPA), an anti-epileptic drug, has been reported to cause male sub/infertility. Together with searching for alternative treatments, the degrees to which testosterone levels and sperm quality are decreased under VPA treatment also need to be clarified. This study aimed to investigate the protective effects of Momordica cochinchinensis (MC) aril extract containing antioxidant capacity on adverse reproductive parameters induced with VPA. Rats were divided into 6 groups (control, VPA, $200 \mathrm{mg} \mathrm{kg}-1 \mathrm{of} \mathrm{MC}$ only, 50, 100, $200 \mathrm{mg} \mathrm{kg-1} \mathrm{MC+VPA,} \mathrm{respectively,} \mathrm{n}=8$ in each). Animals were pretreated with MC extract for 23 days before coadministration with VPA (500 mg kg-1, i.p.) for 10 consecutive days. All reproductive parameters including histology, and expression of androgen receptor (AR), Ki-67, tyrosine phosphorylated proteins, and steroidogenic proteins in testis were examined. The results showed that MC could prevent all reproductive parameters in VPA-treated rats. Moreover, MC+VPA groups showed significant declining of testicular histopathologies compared to VPA group. It also decreased the malondialdehyde level and changes of the testicular StAR, AR, and tyrosine phosphorylated protein expressions. In conclusion, $M$. cochinchinensis aril extract can prevent adverse male reproductive parameters and essential testicular proteins damages induced with VPA.

KEY WORDS: Androgen receptor (AR); Ki-67; Momordica cochinchinensis; Rats; Steroidogenic acute regulatory protein (StAR); Tyrosine testicular phosphorylated protein; Valproic acid.

\section{INTRODUCTION}

Valproic acid (VPA) is an anticonvulsant widely used for treatment of neurological disorders (Bialer \& Yagen, 2007) and an anticancer drug (Glister et al., 2012). However, VPA has been reported to exert side effects on reproductive systems of epileptic patients and animal models including decreases of the FSH, LH and testosterone levels, male reproductive parameters and sperm motility, and various histopathological changes suggesting testicular atrophy (Isojärvi, 2008; Hamza \& Amin, 2007; Iamsaard et al., 2015; Sukhorum et al., 2016; Sukhorum \& Iamsaard, 2017). Moreover, VPA has been shown to increase the malondialdehyde levels in serum and tissue whereas it decreases the activity of antioxidant enzymes in the testis (Hamza \& Amin; Sakr et al., 2014). In addition, some information about the molecular mechanism underlying the effects of VPA on the male reproductive system, especially effects on spermatogenesis and sex hormone production including testicular Ki-67, phosphorylated proteins, steroidogenic acute regulatory protein (StAR), and cholesterol side-chain cleavage enzyme (P450scc) has been published by our group (Sukhorum et al., 2016). Currently, many medicinal plants have been used in searching for alternative treatments to prevent such side effects of VPA administration (Hamza \& Amin; Sakr et al.; Iamsaard et al.). Momordica cochinchinensis (L.) Spreng (MC) or Fag Kaow (also called Gac fruit) has been used as a traditional medicinal plant and alternative food in many countries in Asia. Recently, various scientific studies have shown that MC fruit

\footnotetext{
${ }^{1}$ Department of Anatomy, Faculty of Medicine, Khon Kaen University, 123 Mittaparb Road, Maung, District, Khon Kaen, 40002, Thailand.

${ }^{2}$ Center for Research and Development of Herbal Health Product, Faculty of Pharmaceutical Sciences, Mittaparb Road, Khon Kaen, 40002, Thailand. Grants: This project was financially supported by Research Fund for Supporting Lecture to Admit High Potential Student to Study and Research on His Expert Program (No. 561H214), Graduate School and invitation research grants (No. IN 59106) from the Faculty of Medicine, Khon Kaen University, Thailand.
} 
extract has antioxidant and pharmacological properties (Kubola \& Siriamornpun, 2011; Liu et al., 2012; Zheng et al., 2014). Although MC has been demonstrated to have antioxidant activities and various phyto-therapeutic properties, the preventive effects on molecular mechanism of testicular damage have never been reported. Therefore, this study aimed to investigate the changes of testicular proteins in VPA-treated rats. Additionally, we have also further demonstrated the protective effect of $\mathrm{MC}$ aril extract on other male reproductive organs damaged in VPA-induced rats.

\section{MATERIAL AND METHOD}

Preparation of M. cochinchinensis (MC) aril extract. MC collection and extraction were described in our previous report (Sukhorum et al., 2016). In addition, the antioxidant capacity were already tested such as total phenolic compound, total flavonoid content, DPPH free radical scavenging, and ferric reducing antioxidant power of this extract by Assist. Prof. Somsak Nualkaew, Department of Pharmaceutical Sciences, Faculty of Pharmacy, Mahasarakham University, Mahasarakham, Thailand.

Animals and experimental design. Forty-eight male adult Wistar rats (200-230 g) were obtained from the National Laboratory Animal Center, Salaya, Nakhon Pathom, Thailand. Rats were housed in polycarbonate cages in the animal experiment room a constant temperature $\left(22 \pm 2{ }^{\circ} \mathrm{C}\right)$ under a 12-h light-dark cycle, in North-east Laboratory Animal Center, Khon Kaen University (KKU; Khon Kaen, Thailand). All rats had ad libitum access to a commercial pellet diet and water. Rats were divided into 6 groups $(\mathrm{n}=8)$; control (DW), VPA (500 mg kg-1), MC200 (200 mg kg-1), MC50+VPA (50 mg kg-1), MC100+VPA (100 mg kg-1) and MC200+VPA groups. The experiment periods (divided into two sub-periods: a protective period [days 1-23] and a co-administrative period [days 24-33]) of this study were totally 33 days as followed previous study of our group (Sukhorum et al., 2016). At the end of experiment (day 34), all rats were euthanized with i. p. injecting of concentrated pentobabital sodium. Then, rats were collected for testes in further investigations. This study was approved by Animal Ethics Committee of Khon Kaen University, based on the Ethics of Animal Experimentation of National Research Council of Thailand (Rec. No. AEKKUNELAC 17/2557).

Testicular Ki-67 immunohistochemistry study. The right testis was fixed in $10 \%$ formalin in phosphate buffer saline (PBS). They were routinely paraffin processed, sectioned (5 $\mu \mathrm{m}$-thickness) and placed on glass slides. All sections were processed antigen retrieval, endrogenouse peroxidase blocking, and non-specific proteins blocking, respectively. Then, all sections were probed with rabbit anti-Ki-67 antibody (1:300 (v/v); Millipore, Co., USA) diluted in PBS and incubated. Each section was washed and incubated with a horseradish peroxidase (HRP)-conjugated goat anti-rabbit $\operatorname{IgG}\left(1: 300(\mathrm{v} / \mathrm{v})\right.$; Invitrogen ${ }^{\mathrm{TM}}$, USA). All sections were washed and then were incubated with the Vector NovaRED peroxidase (HRP) substrate kit (Vector Laboratories, USA) for product of this reaction is red color. Continually, sections were dehydrated, cleared, and mounted with DPX, respectively. All section images were photographed at magnification x 400, using a Nikon light ECLIPSE E200 microscope equipped with a DXM1200 digital camera (Nikon, Japan).

Testicular protein preparation and western blot analysis. The testis at left side was homogenized with RIPA buffer (Cell Signaling Technology, Inc., USA) containing a protease inhibitor cocktail (Sigma-Aldrich, Inc., USA). The total protein concentration was measured by using a NanoDrop ND-1000 Spectrophotometer (NanoDrop Technologies, Inc., USA) at an absorbance of $280 \mathrm{~nm}$. All testicular proteins were separated in $10 \%$ or $8 \%$ (for Ki-67 protein) gel SDSPAGE. Subsequently, the separated proteins were transferred membrane. The membranes were then incubated with $5 \%$ skim-milk blocking solution and they were further incubated with anti-phosphotyrosine 4G10 antibody (1: 1000 (v/v); Millipore), anti-StAR antibody (1: 2000 (v/v); Santa Cruz Biotechnology), anti-AR antibody (1: 200 (v/v); Santa Cruz Biotechnology), anit-Ki-67 antibody (1: 1000 (v/v); Millipore) or an anti-b-actin antibody (1:1000 (v/v); Santa Cruz Biotechnology; internal control). After membranes were washed, then they were incubated with a horseradish peroxidase-conjugated secondary antibody specific to the primary antibody. Then, the expression of target proteins was detected using an enhanced chemiluminescence (ECL) substrate reagent kit (GE Healthcare Life Sciences) and the ImageQuant 400 imaging system (GH Healthcare Life Sciences). For the intensity of bands proteins expression, it was quantified using ImageJ program. The bovine serum albumin (BSA; Millipore), epidermal growth factor (EGF; Millipore) and StAR lysate were used as a negative or positive control.

Testicular malondialdehyde (MDA) level measurement. The testicular MDA molecule and proteins were extracted from left testis tissue using RIPA buffer containing a protease inhibitor cocktail and they were homogenated using grinder and ultrasonic homogenizer (Microprocessor controlled 100 Watt Model). Then, the testicular homogenate was centrifuged to separate the testicular lysate supernatant from the pellet. Subsequently, the total protein concentration of 
the testicular supernatant was measured using a NanoDrop ND-1000 Spectrophotometer at absorbance of $280 \mathrm{~nm}$. For testicular lysate, the concentration of testicular MDA was measured by TBARS assay as applied from Luangaram et al. (2007). Briefly, testicular lysate was mixed with TBARS reagents. Then, the mixture was boiled in water bath. The cooling mixture was centrifuged. The supernatant of mixture (pink) was measured using Spectrophotometer (UV/VIS) (Evolution 600, Thermo Scientific, USA) at absorbance 534 $\mathrm{nm}$. The MDA concentration was expressed as nMol MDA/ $\mathrm{mg}$ protein. A standard curve was plotted from appropriate concentrations (2-25 nMol) of 1,1,3,3-tetraethoxypropane (TEP).

Statistical analysis. Prior to determining the significance of differences between groups using SPSS version 19.0 (IBM SPSS Statistics), all data were first-subjected to the ShapiroWilk test (W-test) to confirm normal distribution and equality of variances. To compare the differences among groups, one-way ANOVA (analysis of variance) was used for data normally-distributed while the Kruskal-Wallis (or H test) was used for none normally distributed data. Two-sided Pvalue $<0.05$ was considered as significant difference. Data are expressed as the mean \pm standard deviation (S. D.).

\section{RESULTS}

Effects of MC aril extract on the testicular phosphorylated tyrosine proteins expression. Western blotting analysis of testicular lysates revealed 6 majors bands (21-, 28-, 32-, 34-, 39-, and 49- kDas) of testicular tyrosine phosphorylated proteins which are detected in all groups (Fig. 1A). However, there are different four bands (32-, 34-, 39-, and 49- kDas) of such proteins that can be quantified for the intensity of protein expressions by comparing with control group (Fig. 1). The expression of 32- and 34- kDas phosphorylated protein (Fig. 1B), the intensity result showed that expression of this protein was significantly increased $(\mathrm{P}<0.05)$ in $\mathrm{MC} 200$ group to the compared with control group. In contrast, this protein of VPA-treated group was significantly decreased $(\mathrm{P}<0.05)$ as compared with control and MC200 groups. Moreover, the expression of 32- $\mathrm{kDa}$ protein in MC100+VPA group was significantly increased $(\mathrm{P}<0.05)$ when compared with VPA-treated group. For expression of 39- kDa, MC extracts and VPA did not affect a $39 \mathrm{kDa}$ testicular phosphorylated protein compared with control groups. The result showed that $49 \mathrm{kDa}$ protein's intensity was
A

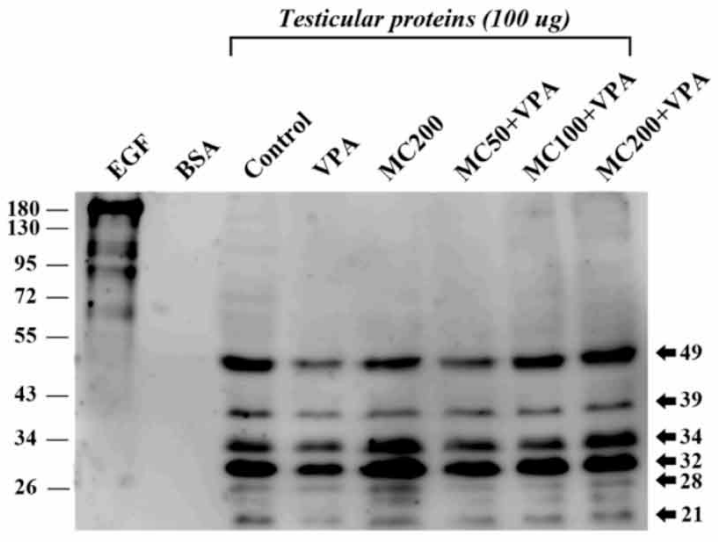

B

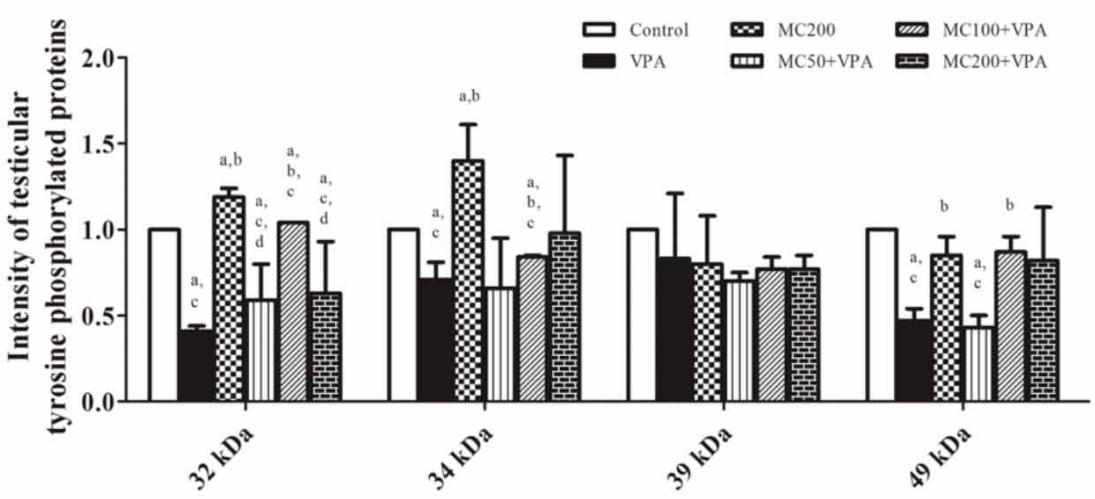

Fig. 1. (A) Western blotting analysis of phosphorylated tyrosine proteins in testicular lysates (pool sample) of control and treated groups. Bovine serum albumin (BSA) and epidermal growth factor (EGF)-like growth factor used as a negative and positive control, respectively. (B) Intensity changes of $32,34,39$, and $49 \mathrm{kDas}$ phosphorylated tyrosine proteins compared between control and treated groups. Data are the mean $\pm \mathrm{S}$. D.; a, significant difference $(\mathrm{P}<0.05)$ as compared with control group; $\mathrm{b}$, significant difference $(\mathrm{P}<0.05)$ as compared with VPA group; c, significant difference $(\mathrm{P}<0.05)$ as compared with MC200 group; d, significant difference $(\mathrm{P}<0.05)$ as compared with MC100+VPA. 
significantly decreased $(\mathrm{P}<0.05)$ in MC200 group when compared with control group. Moreover, the expressions of this protein of VPA-treated and MC50+VPA groups were significantly decreased $(\mathrm{P}<0.05)$ compared to control and MC200 groups. Therefore, it was found that MC200 induced the intensity of testicular phosphorylated proteins at 32- and 34- kDas as shown to be higher than those in the control group. In contrast, MC extract (200 mg kg-1) reduced the expression of phosphorylated protein at 49$\mathrm{kDa}$ compared with the control. Moreover, the results showed that the expressions of 32-, 34-, and 49- kDas proteins in VPA treated group were significantly lower than that of the control and MC200 groups. Furthermore, MC100+VPA group showed improvement of the testicular phosphorylated proteins at 32-, 34- and 49- kDas compared with VPA-treated group (Fig. 1).

Effects of MC aril extract on the testicular Ki-67 protein. AR proteins in testicular lysate were detected with anti AR (N-20) by western blotting (Fig. 2A). The intensity of AR was calculated from intensity of AR band per intensity of b-actin band. The results showed that the expression of testicular AR protein in VPA treated group was significantly lower $(\mathrm{P}<0.05)$ than that as compared to the control and $\mathrm{MC}$ treated groups (MC200, MC50+VPA, MC100+VPA, and MC200+VPA). Moreover, the expression of AR protein in $\mathrm{MC} 100+\mathrm{VPA}$ group was significantly improved $(\mathrm{P}<0.05)$ when compared with VPA-treated rats.
For StAR protein expressions, the results showed that MC extracts (MC50+VPA, MC100+VPA, and MC200+VPA) significantly improved the expressions of StAR protein $(\mathrm{P}<0.05)$ in dose dependent as compared to VPA-treated rats (Fig. 2B). However, the StAR protein expressions in co-treatments (MC50+VPA, MC100+VPA, and $\mathrm{MC} 200+\mathrm{VPA})$ were significantly lower than $(\mathrm{P}<0.05)$ that of the control group (Fig. 2B). In addition, the results showed that MC extract (200 mg kg-1) did not change the testicular StAR protein expression as compared the control group (Fig. 2B).

Moreover, western blotting analysis of testicular lysates revealed a $\mathrm{Ki}-67$ protein of testicular lysate was detected at a 395- kDa protein band (Fig. 2C). Moreover, to quantify the changes of Ki- 67 protein expression, the results were showed that the intensities of $\mathrm{Ki}-67$ protein in all treated group (VPA, MC200, MC50+VPA, MC100+VPA, and MC200+VPA) were significantly lower $(\mathrm{P}<0.05)$ than that of the control groups. However, intensity of this protein in MC200 group tended to increase as compared with VPAadministrated groups. Furthermore, intensity of Ki-67 protein in MC100+VPA group was shown that it tended to increase as compared with VPA-treated group (Fig. 2C).

Effects of MC aril extract on the localization of $\mathrm{Ki}$ 67 protein on testis. The presence of Ki-67 protein in testicular tissue was also investigated by
A

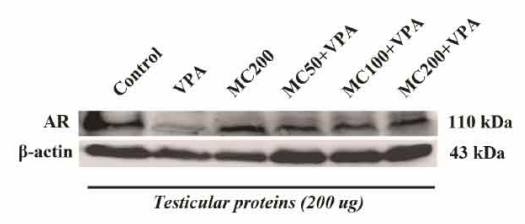

(b)

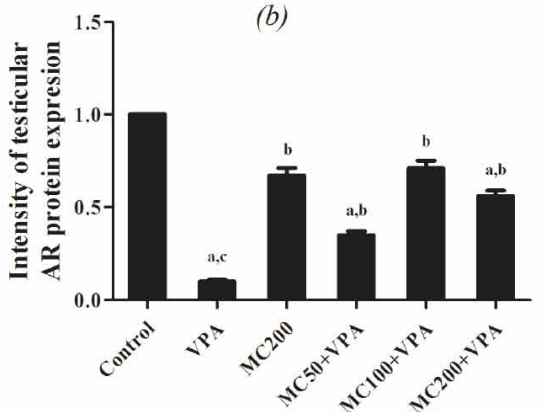

B

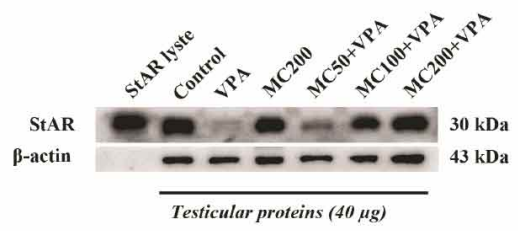

(b)

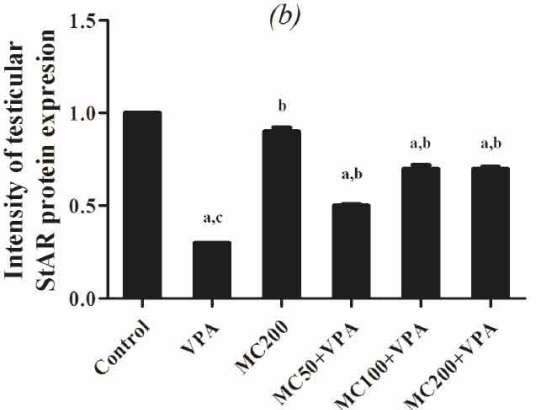

$\mathbf{C}$

(a)

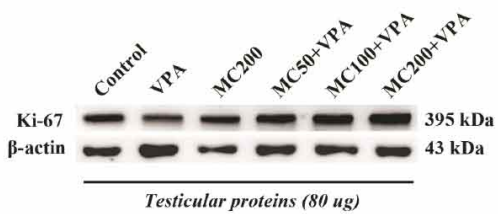

(b)

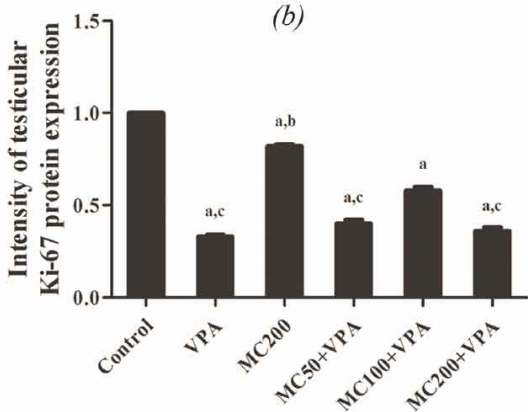

Fig. 2 (a) Western blotting analyses of androgen receptor; AR (A), steroidogenic acute regulatory (StAR) proteins (B), and Ki-67 (C) in testicular lysates ( $\mathrm{n}=5$ in each group) of control and treated groups. StAR lysate was used as a positive control. b-Actin was used as an internal control. (b) Relative intensity of testicular AR, StAR, and Ki-67 protein expressions of control and treated groups. Data are expressed as the mean \pm S. D.; a, significant difference $(\mathrm{P}<0.05)$ as compared with control group; b, significant difference $(\mathrm{P}<0.05)$ as compared with VPA group; c, significant difference $(\mathrm{P}<0.05)$ as compared with MC200 group. 
immunohistochemistry localization. Fig. 3 shows localization of testicular Ki-67 protein within in nuclei of Sertoli cells and spermatogonia (dark red color as considered to be positive cells). Moreover, it was found that that this protein was greatly localized in Sertoli cells more than spermatogonia of testicular control and MC200 groups (Fig. 3B, 3D). In contrast, this presence of spermatogonia was higher than Sertoli cells which was found in sections of VPA, MC50+VPA, MC100+VPA, and MC200+VPA (Fig. 3C, 3E, 3F, 3G).
Testicular malondialdehyde (MDA) levels. The results showed that MDA levels in testicular lysate of VPAtreated rat was significantly higher $(\mathrm{P}<0.05)$ than that of the control rats (Fig. 4). In addition, MC extracts could reduce the MDA level in VPA-treated rats. Moreover, MC extract at dose $100 \mathrm{mg} \mathrm{kg}-1$ significantly decreased $(\mathrm{P}<0.05)$ the MDA level as compared with VPA-treated rat. In addition, this study showed that MC200 did not affect testicular MDA level when compared with control rats.

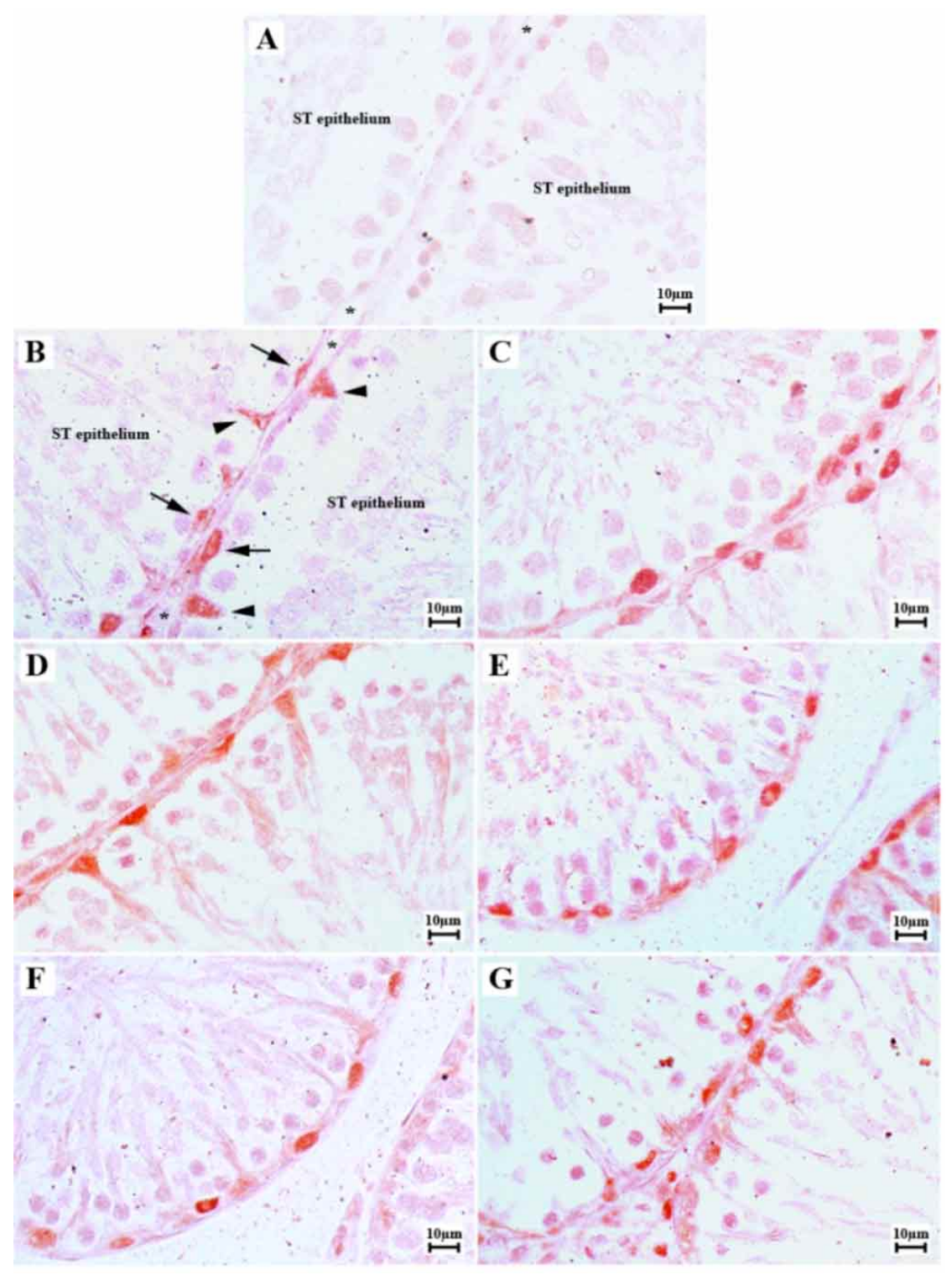

Fig. 3 Immunohistochemical localization using polyclonal antibody for Ki-67 on testicular sections of control (B), VPA-treated (C), MC200 (D), MC50+VPA (E), MC100+VPA (F), and MC200+VPA (G) groups. Representative areas (magnification of $\mathrm{x} 400$ ) showing positive staining are Sertoli cells (arrow heads) and spermatogonia (arrows) present as red dark color compared with negative control (A). ST epithelium indicates the seminiferous tubule epithelium and asterisks are interstitial space. 


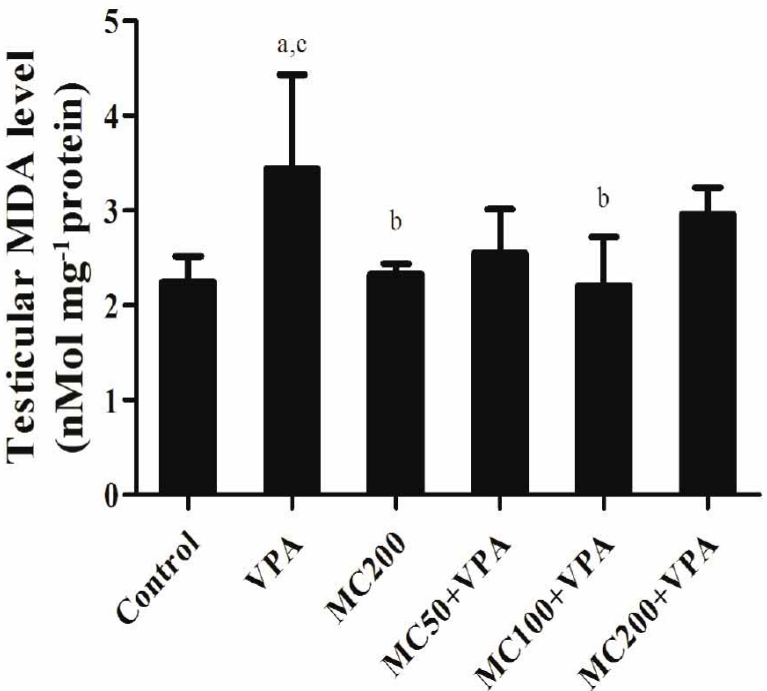

Fig. 4. Showing concentration of testicular malondialdehyde (MDA) of control and treated groups using thiobarbituric acid reactive substance (TBARS) assay. MDA levels are shown per protein concentration from testicular lysate (nMol mg-1 protein). Data are expressed as the mean \pm S. D.; a, significant difference $(\mathrm{P}<0.05)$ as compared with control group; $\mathrm{b}$, significant difference $(\mathrm{P}<0.05)$ as compared with VPA group; $\mathrm{c}$, significant difference $(\mathrm{P}<0.05)$ as compared with MC200 group.

\section{DISCUSSION}

The present study has demonstrated that MC aril extract could improved the changes of the testicular StAR protein, androgen receptor (AR), and tyrosine phosphorylated (32-, 34-, 49-kDa) proteins expression in VPA-treated rats. Moreover the testicular malondialdehyde (MDA) level in VPA-treated rats was significantly decreased by protective effect of MC extract. Recently, a previous study of our group showed that MC extract has indeed protective effects on testicular damage induced by VPA (Sukhorum $e t$ al., 2016). It was described by present study that MC aril extract significantly reduced the testicular MDA level in male rats induced with VPA (Fig. 4). In consistency to other reports, MC aril extract has been reported to have high antioxidant activities (Kubola \& Siriamornpun). Since MC extract has been proved for its high antioxidant activities (Kubola \& Siriamornpun), besides decreasing of MDA, it has been assumed that MC aril extract may have abilities in increasing of catalase and glutathione peroxidase in the testicular tissue as previously reported (Hamza \& Amin; Sakr et al.). Such activities may be the actions of high caratenoids, especially lycopene and b-carotene contents (Aoki et al., 2002; Kubola \& Siriamornpun; Kubola et al., 2013) and vitamin E (Vuong le et al., 2002). Therefore, MC aril extract containing high antioxidant capacity could prevent adverse reproductive parameters of VPA-treated rats as previously reported (Hamza \& Amin; Sakr et al.; Iamsaard et al.; Ourique et al., 2016) via oxidative pathways. The biochemical and molecular analyses were performed to explain additional mechanisms of how the MC could prevent such adverse effects. The protective tissue damage effect demonstrated in this study is a phytotherapeutic property of MC extract besides other pharmacological properties shown in previous reports (Liu et al.; Zheng et al.). Moreover, present study found that MC improved expression of these phosphorylated proteins (Fig. 1) which associated with increased sperm concentration in MC+VPA groups (Sukhorum et al., 2016). In general, Ki-67 protein is a cell proliferative marker (Steger et al., 1998; Whitfield et al., 2006; Angelopoulou et al., 2008). In testis, it presents in the nuclei of spermatogonia and Sertoli cells (Steger et al.; Schwalm et al., 2007). For immunohistochemistry of antiKi-67 protein result in this study, this protein was also detected in nuclei of spermatogonia and Sertoli cells (Fig. 3 ) as shown in previous reports. Additionally, the expression of Ki-67 protein was quantified using western blotting. The result showed that the Ki-67 expressions in both VPA- and MC-treated groups were lower than control group. This study suggested that low expression of this protein might associate with the decreasing of germ cell proliferation resulting in testicular damages, spermatogenic arrest, and damage of seminiferous tubule as demonstrated in previously reports (Steger et al.; Schwalm et al.). In testis, testosterone hormone is synthesized within Leydig cell. The precursors of this hormone are cholesterols and further transferred onto the mitochondrial membrane via StAR protein binding. In general steroidogenic cells, previous in vitro studies have demonstrated that VPA significantly decreased the gene expressions of STAR, CYP11A1 and CYP17A1 (Gustavsen et al., 2009; Glister et al.). The low expressions of such proteins are usually explained the direct causes of low testosterone hormone production. In addition, the AR is testosterone hormone receptor expressed in Sertoli cells, peritubular myoid cells, and Leydig cells of testis and in epithelial and stromal cells of the epididymis (Anthony et al., 1989; Zhu et al., 2000). This receptor signaling is important for the steps of spermatogenesis to maintain sperm production (O'Hara \& Smith, 2015). Additionally, VPA was shown to reduce testosterone levels (Bauer et al., 2004; Herzog et al., 2004; Sukhorum et al., 2017) but actual mechanism of that effect was still unexplained. To clarify that issue, this study demonstrated that the low expression of testicular StAR and AR proteins in VPA-treated rat as compared with control. It was found that the MC extract could also improve the expression of these proteins. However, the mechanism of MC action on the upregulation 
of StAR and AR proteins is still unknown. Previous reports have explained that the action of VPA is involved in oxidative stress in male reproductive system (Hamza \& Amin; Khan et al., 2011; Ourique et al.) by causing testicular DNA damage (Sakr et al.; Durairajanayagam et al., 2014). All together with previous reports, $\mathrm{MC}$ is an antioxidant plant that has efficacy to prevent the oxidative stress form VPA treatment. In conclusion, our study indicates that $\mathrm{MC}$ aril extract is safe for use and can protect the adverse male reproductive parameters in treatment with VPA.

\section{ACKNOWLEDGMENTS}

This project was financially supported by Research Fund for Supporting Lecture to Admit High Potential Student to Study and Research on His Expert Program (No. 561H214), Graduate School and invitation research grants (No. IN 59106) from the Faculty of Medicine, Khon Kaen University, Thailand.

SITTHICHAI, I.;WANNISA, S.; APICHAKARN, S. \& BUNGORN, S. Efecto protector de Momordica cochinchinensis (L.) extracto de aril en marcadores testiculares esenciales en ratas inducidas con ácido valproico. Int. J. Morphol., 35(3):992-999, 2017.

RESUMEN: Se ha informado que el ácido valproico (VPA), un fármaco antiepiléptico, causa infertilidad masculina. Junto con la búsqueda de tratamientos alternativos, los grados a los que los niveles de testosterona y la calidad del esperma son disminuidos bajo el tratamiento de VPA también necesitan ser aclarados. El objetivo de este estudio fue investigar los efectos protectores del extracto aril de Momordica cochinchinensis (MC) que contiene capacidad antioxidante sobre parámetros reproductivos adversos inducidos con VPA. Las ratas se dividieron en 6 grupos (control, VPA, $200 \mathrm{mg} \mathrm{kg-1}$ de MC solamente, 50, 100, 200 mg kg-1 de MC + VPA, respectivamente; $n=8$ en cada uno). Los animales fueron pretratados con extracto de MC durante 23 días antes de la coadministración con VPA (500 mg kg-1, i.p.) durante 10 días consecutivos. Se examinaron todos los parámetros reproductivos, incluyendo la histología, y la expresión de receptor de andrógenos (AR), Ki-67, proteínas fosforiladas con tirosina y proteínas esteroidogénicas en los testículos. Los resultados mostraron que MC podría prevenir todos los parámetros reproductivos en las ratas tratadas con VPA. Además, los grupos MC + VPA mostraron una disminución significativa de las histopatologías testiculares en comparación con el grupo VPA. También disminuyó el nivel de malondialdehído y los cambios de las expresiones testiculares de las proteínas StAR, AR y tirosina fosforiladas. En conclusión, el extracto de aril de M. cochinchinensis puede prevenir los parámetros reproductivos masculinos adversos y los daños esenciales de proteínas testiculares inducidos con VPA.
PALABRAS CLAVE: Receptor de andrógenos (AR); Ki - 67; Momordica cochinchinesis; Ratas; Proteína reguladora aguda esteroideica (StAR); Tirosina proteína fosforilada testicular; Ácido valproico.

\section{REFERENCES}

Angelopoulou, R.; Balla, M.; Lavranos, G.; Chalikias, M.; Kitsos, C.; Baka, S. \& Kittas, C. Evaluation of immunohistochemical markers of germ cells' proliferation in the developing rat testis: a comparative study. Tissue Cell, 40(1):43-50, 2008.

Anthony, C. T.; Kovacs, W. J. \& Skinner, M. K. Analysis of the androgen receptor in isolated testicular cell types with a microassay that uses an affinity ligand. Endocrinology, 125(5):2628-35, 1989.

Aoki, H.; Kieu, N. T.; Kuze, N.; Tomisaka, K. \& Van Chuyen, N. Carotenoid pigments in GAC fruit (Momordica cochinchinensis SPRENG). Biosci. Biotechnol. Biochem., 66(11):2479-82, 2002.

Bauer, J.; Blumenthal, S.; Reuber, M. \& Stoffel-Wagner, B. Epilepsy syndrome, focus location, and treatment choice affect testicular function in men with epilepsy. Neurology, 62(2):243-6, 2004.

Bialer, M. \& Yagen, B. Valproic Acid: second generation. Neurotherapeutics, 4(1):130-7, 2007.

Durairajanayagam, D.; Agarwal, A.; Ong, C. \& Prashast, P. Lycopene and male infertility. Asian J. Androl., 16(3):420-5, 2014.

Glister, C.; Satchell, L.; Michael, A. E.; Bicknell, A. B. \& Knight, P. G. The anti-epileptic drug valproic acid (VPA) inhibits steroidogenesis in bovine theca and granulosa cells in vitro. PLoS One, 7(11):e49553, 2012.

Gustavsen, M. W.; von Krogh, K.; Taubøll, E.; Zimmer, K. E.; Dahl, E.; Olsaker, I.; Ropstad, E. \& Verhaegen, S. Differential effects of antiepileptic drugs on steroidogenesis in a human in vitro cell model. Acta Neurol. Scand. Suppl., (189):14-21, 2009.

Hamza, A. A. \& Amin, A. Apium graveolens modulates sodium valproateinduced reproductive toxicity in rats. J. Exp. Zool. A Ecol. Genet. Physiol., 307(4):199-206, 2007.

Herzog, A. G.; Drislane, F. W.; Schomer, D. L.; Pennell, P. B.; Bromfield, E. B.; Kelly, K. M.; Farina, E. L. \& Frye, C. A. Differential effects of antiepileptic drugs on sexual function and reproductive hormones in men with epilepsy: interim analysis of a comparison between lamotrigine and enzyme-inducing antiepileptic drugs. Epilepsia, 45(7):764-8, 2004.

Iamsaard, S.; Arun, S.; Burawat, J.; Sukhorum, W.; Boonruangsri, P.; Namking, M.; Uabundit, N.; Nualkaew, S. \& Sripanidkulchai, S. Phyllanthus emblica L. branch extract ameliorates testicular damage in valproic acid-induced rats. Int. J. Morphol., 33(3):1016-22, 2015.

Isojärvi, J. Disorders of reproduction in patients with epilepsy: antiepileptic drug related mechanisms. Seizure, 17(2):111-9, 2008.

Khan, S.; Ahmad, T.; Parekh, C. V.; Trivedi, P. P.; Kushwaha, S. \& Jena, G. Investigation on sodium valproate induced germ cell damage, oxidative stress and genotoxicity in male Swiss mice. Reprod. Toxicol., 32(4):38594, 2011.

Kubola, J. \& Siriamornpun, S. Phytochemicals and antioxidant activity of different fruit fractions (peel, pulp, aril and seed) of Thai gac (Momordica cochinchinensis Spreng). Food Chem., 127(3):1138-45, 2011.

Kubola, J.; Meeso, N. \& Siriamornpun, S. Lycopene and beta carotene concentration in aril oil of gac (Momordica cochinchinensis Spreng) as influenced by aril-drying process and solvents extraction. Food Res. Int., 50(2):664-9, 2013.

Liu, H. R.; Meng, L. Y.; Lin, Z. Y.; Shen, Y.; Yu, Y. Q. \& Zhu, Y. Z. Cochinchina momordica seed extract induces apoptosis and cell cycle arrest in human gastric cancer cells via PARP and p53 signal pathways. Nutr. Cancer, 64(7):1070-7, 2012.

Luangaram, S.; Kukongviriyapan, U.; Pakdeechote, P.; Kukongviriyapan, V. \& Pannangpetch, P. Protective effects of quercetin against 
SITTHICHAI, I.; WANNISA, S.; APICHAKARN, S. \& BUNGORN, S. Protective effect of Momordica cochinchinensis (L.) spreng aril extract on essential testicular markers in rats induced with valproic acid. Int. J. Morphol., 35(3):992-999, 2017.

phenylhydrazine-induced vascular dysfunction and oxidative stress in rats. Food Chem. Toxicol., 45(3):448-55, 2007.

O'Hara, L. \& Smith, L. B. Androgen receptor roles in spermatogenesis and infertility. Best Pract. Res. Clin. Endocrinol. Metab., 29(4):595-605, 2015.

Ourique, G. M.; Saccol, E. M.; Pês, T. S.; Glanzner, W. G.; Schiefelbein, S. H.; Woehl, V. M.; Baldisserotto, B.; Pavanato, M. A.; Gonçalves, P. B. $\&$ Barreto, K. P. Protective effect of vitamin E on sperm motility and oxidative stress in valproic acid treated rats. Food Chem. Toxicol., 95:159-67, 2016.

Sakr, S. A.; Zowail, M. E. \& Marzouk, A. M. Effect of saffron (Crocus sativus L.) on sodium valporate induced cytogenetic and testicular alterations in albino rats. Anat. Cell Biol., 47(3):171-9, 2014.

Schwalm, A.; Gauly, M.; Erhardt, G. \& Bergmann, M. Changes in testicular histology and sperm quality in llamas (Lama glama), following exposure to high ambient temperature. Theriogenology, 67(8):1316-23, 2007.

Steger, K.; Aleithe, I.; Behre, H. \& Bergmann, M. The proliferation of spermatogonia in normal and pathological human seminiferous epithelium: an immunohistochemical study using monoclonal antibodies against Ki-67 protein and proliferating cell nuclear antigen. Mol. Hum. Reprod., 4(3):227-33, 1998.

Sukhorum, W. \& Iamsaard, S. Changes in testicular function proteins and sperm acrosome status in rats treated with valproic acid. Reprod. Fertil. Dev., 29(8):1585-92, 2017.

Sukhorum, W.; Sampannang, A.; Sripanidkulchai, B. \& Iamsaard, S. Momordica cochinchinensis (L.) Spreng: Aril extract prevents adverse reproductive parameters of male rats induced with valproic acid. Int. J. Morphol., 34(3):870-6, 2016.

Vuong le, T.; Dueker, S. R. \& Murphy, S. P. Plasma beta-carotene and retinol concentrations of children increase after a 30-d supplementation with the fruit Momordica cochinchinensis (gac). Am. J. Clin. Nutr., 75(5):872-9, 2002.

Whitfield, M. L.; George, L. K.; Grant, G. D. \& Perou, C. M. Common markers of proliferation. Nat. Rev. Cancer, 6(2):99-106, 2006.

Zheng, L.; Zhang, Y. M.; Zhan, Y. Z. \& Liu, C. X. Momordica cochinchinensis seed extracts suppress migration and invasion of human breast cancer ZR-75-30 cells via down-regulating MMP-2 and MMP9. Asian Pac. J. Cancer Prev., 15(3):1105-10, 2014.

Zhu, L. J.; Hardy, M. P.; Inigo, I. V.; Huhtaniemi, I.; Bardin, C. W. \& MooYoung, A. J. Effects of androgen on androgen receptor expression in rat testicular and epididymal cells: a quantitative immunohistochemical study. Biol. Reprod., 63(2):368-76, 2000.

\author{
Corresponding author: \\ Dr. Sitthichai lamsaard \\ Department of Anatomy \\ Faculty of Medicine \\ Khon Kaen University \\ 123 Mitraparp Road \\ Amphoe Muang, Khon Kaen 40002 \\ THAILAND
}

\section{E-mail: sittia@kku.ac.th}

Received: 18-03-2017

Accepted: 12-06-2017 